\title{
Characterisation of Protein Isolates Prepared from Processed Mungbean (Vigna radiata) Flours
}

\author{
Daniel J. Skylas ${ }^{1,2}$, Mark P. Molloy ${ }^{3,4}$, Robert D. Willows ${ }^{3}$, Christopher L. Blanchard ${ }^{2} \&$ Ken J. Quail ${ }^{1}$ \\ ${ }^{1}$ Australian Export Grains Innovation Centre, North Ryde, NSW, Australia \\ ${ }^{2}$ ARC Industrial Transformation Training Centre for Functional Grains, Charles Sturt University, Wagga Wagga, \\ NSW, Australia \\ ${ }^{3}$ Department of Chemistry and Biomolecular Sciences, Macquarie University, Sydney, NSW, Australia \\ ${ }^{4}$ Australian Proteome Analysis Facility, Macquarie University, Sydney, NSW, Australia \\ Correspondence: Daniel J. Skylas, Australian Export Grains Innovation Centre, North Ryde, NSW, Australia. Tel: \\ 61-(0)2-8025-3200. E-mail: daniel.skylas@aegic.org.au
}

\author{
Received: July 31, $2017 \quad$ Accepted: October 10, $2017 \quad$ Online Published: November 15, 2017 \\ doi:10.5539/jas.v9n12p1 \\ URL: https://doi.org/10.5539/jas.v9n12p1
}

\begin{abstract}
Pulses are normally processed prior to consumption, are high in protein, providing opportunities for improving nutritional qualities of food. Processing methods can modify nutritional properties, affecting protein content, composition and functionality. In this study, we investigated the effect of processing methods on protein concentration and yield from protein isolates prepared by alkaline solubilisation and isoelectric precipitation, from whole seed flour, raw dahl flour, roasted dahl flour and germinated flour of mungbean. Protein isolates

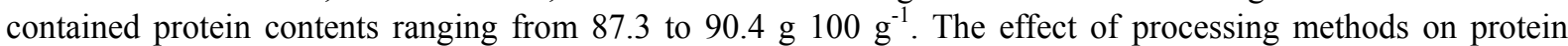
solubility characteristics was evident, as protein yields ranged from 75.7 (whole seed flour), 80.8 (raw dahl

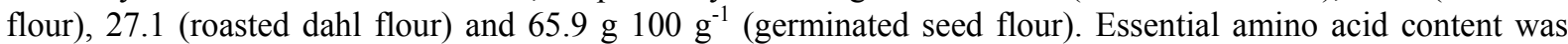

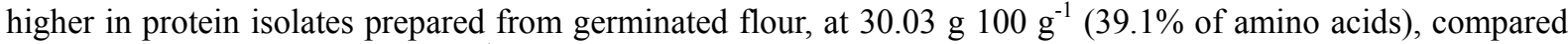

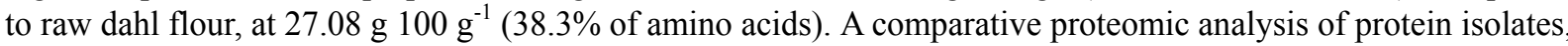
prepared from raw dahl and germinated flour, resulted in the inferred identification of 214 proteins from protein sequence databases, in which, 72 proteins were classified as being common, 42 proteins specific to raw dahl flour and 28 proteins specific to germinated flour. Processing methods such as roasting and germination can significantly alter flour protein solubility, consequently, impacting on overall efficiency of protein extraction. The comparative proteomic analysis used in this study proved to be useful for investigating changes in protein composition and relative abundance, highlighting the potential in applying this technology for further characterisation of modified protein fractions for food applications.
\end{abstract}

Keywords: mungbean, processing, protein, solubility, proteomics

\section{Introduction}

The global demand for protein is rapidly increasing due to world population growth and rising affluence in developing countries, consequently, increasing consumer demand for animal protein, resulting in significant impact on the environment (Aiking, 2011). Increasing plant protein production is a more sustainable approach for supplying this protein in the long term. Pulses include chickpea, field pea, lupin, fababean and mungbean, are generally high in protein and also provide agronomic benefits such as fixing atmospheric nitrogen into the soil, as well as disrupting disease and weed cycles when grown in rotation with cereals. Pulses provide considerable opportunities for improving the nutritional properties in food, which can be facilitated by developing value-added functional pulse protein products with enhanced digestibility and bioavailability of amino acids for metabolism (Tharanathan \& Mahadevamma, 2003; Boye et al., 2010; Nair et al., 2013; Vaz Patto et al., 2015).

One way of increasing consumption of pulses in the future is the development of innovative processing technologies, for production of a diverse range of value-added products, processes and applications. Processing of pulses is carried out in order to modify or enhance nutritional properties, functionality and sensory attributes, as well as increasing palatability, improving shelf life, reducing cooking time and increasing consumer acceptance (Tharanathan \& Mahadevamma, 2003; Boye et al., 2010; Vaz Patto et al., 2015; Patterson et al., 
2017). Processing can be classified as being primary or secondary, with primary processing including de-hulling, splitting, flaking and milling, imparting important processing characteristics, such as particle size distribution, nutritional content and functionality. Secondary processing technologies are increasingly more diverse, consisting of a range of thermal and non-thermal processes, such as roasting, toasting, microwaving, canning, extrusion, soaking, germination (sprouting) and fermentation (Knorr et al., 2011; Sun-Waterhouse et al., 2014; Singh et al., 2015; Patterson et al., 2017).

Pulse flours can also be fractionated for the purpose of concentrating macronutrients such as protein, dietary fibre and starch. Protein can be concentrated from pulse flours using wet extraction techniques or dry processing methods such milling, sieving and air classification, depending on the desired level of protein concentration, source of plant material, scale of operation and cost. Wet processing techniques are usually based on exploiting protein solubility characteristics, generally achieving higher protein concentration and yield, which can be facilitated using specific enzymes to enhance extraction. Traditionally, concentration of plant proteins has been carried out using methods such as alkaline solubilisation and isoelectric precipitation (Fan \& Sosulski, 1974; Thompson, 1977). An evaluation of protein isolates prepared from sixteen mungbean cultivars, ranging from 69.2-74.9\% protein, reported significant variations in functional properties ( $\mathrm{Li}$ et al., 2010). Wet extraction of mungbean protein has previously been evaluated by response surface methodology experiments, optimising aqueous extraction conditions, such as flour to water ratio, $\mathrm{pH}$ conditions, centrifugation, temperature and extraction time (Wang et al., 2011).

Technological developments for characterising protein composition have rapidly progressed since the early days of gel electrophoresis, providing high-throughput separation, characterisation, quantitation and identification of proteins (Thelen \& Peck, 2007; Matros et al., 2011). Advances in mass spectrometry (MS) and bioinformatics provide alternate approaches for comparative proteomic analyses. Spectral counting (SC) is based on counting the number of identified peptide spectra as proxy for protein abundance (Neilson et al., 2013; Lundgren et al., 2010). Proteins are digested with trypsin and the resulting peptide mixture is separated using liquid chromatography (LC) coupled in line with MS/MS (LC-MS/MS). Resulting spectra can then be used to search protein sequence databases to infer protein identification. More abundant digested proteins will produce more spectra, resulting in more peptides belonging to that protein being identified. The number of spectra assigned to individual proteins in a particular sample can be used to measure relative abundance (Liu et al., 2004; Zhang et al., 2006; Zybailov et al., 2007; Nielson et al., 2013). Quality of SC data has improved with the application of normalised spectral abundance factors (NSAF), which account for the fact that longer proteins produce more spectra, which can affect measurements of relative abundance. NSAFs enable comparison of relative protein abundance in which statistical analyses can be applied (Neilson et al., 2013; Zhang et al., 2006; Zybailov et al., 2006; Zybailov et al., 2007; Mosley et al., 2009; Podwojski et al., 2010). Further developments and applications of quantitative proteomics in plants have recently been reported (Matros et al., 2011; Mirzaei et al., 2016).

In this study, the objective was to determine the effect of different processing methods on the production of protein isolates prepared from mungbean flours. A comparative proteomic approach was applied to selected protein isolates for characterisation of protein composition, providing a measure of the relative abundance of these proteins in protein isolates prepared from raw dahl flour and germinated flour.

\section{Experimental}

\subsection{Seed Material and Processing}

Mungbean whole seed material, commercially milled dahl (in kibble form), and roasted mungbean flour were provided by the Blue Ribbon Group (Richlands, QLD 4077). All seed and flour material provided for this study were produced from the mungbean variety known as Crystal, the dominant variety grown and produced in Australia. For germination, mungbean whole seeds were cleaned in absolute ethanol for 1 minute, rinsed three times with distilled water and drained. Sufficient fresh water was added to soak and imbibe the seeds overnight for 12 hours. Soaked seeds were then rinsed, drained and allowed to germinate for 48 hours in a controlled incubator $\left(22{ }^{\circ} \mathrm{C}\right)$. Germinated seeds including hulls were oven dried at $50{ }^{\circ} \mathrm{C}$ on trays to remove excess moisture content. Dried seeds were thrashed in a $2 \mathrm{~mm}$ screen sieve to remove the seed shoots. Whole seed, dahl (kibble) and germinated seed samples were milled to flour using an Alpine pin mill. Processed mungbean flours were designated herein as whole seed (MWF), raw dahl (MDF), roasted dahl (MRF) and germinated (MGF).

\subsection{Wet Processing of Mungbean Flours}

Alkaline solubilisation and isoelectric precipitation was used for the preparation of protein isolates (Wang et al., 2011). Mungbean flour was suspended in water pre-heated to $35^{\circ} \mathrm{C}(1: 10 \mathrm{w} / \mathrm{v})$ and the $\mathrm{pH}$ was adjusted to $\mathrm{pH} 9$ using $\mathrm{NaOH}$ and mixed thoroughly for $30 \mathrm{~min}$ using a magnetic stirrer. The slurry was centrifuged at $12,000 \times \mathrm{g}$ 
for 20 minutes using a Sorvall Lynx 400 laboratory centrifuge. The alkaline supernatant, containing soluble protein, was decanted and transferred to a clean beaker, adjusted to $\mathrm{pH} 4.5 \mathrm{using} \mathrm{HCl}$ and allowed to mix for 10 min. Precipitated protein was recovered by centrifugation at $12,000 \times \mathrm{g}$ for 20 minutes, collected, oven dried at $60{ }^{\circ} \mathrm{C}$, weighed and ground for analysis. Protein extractions were carried out in duplicate for each flour sample and average results reported.

\subsection{Protein Content and Nitrogen Solubility}

Nitrogen content was determined by the Dumas method using a LECO TruMac protein analyser (AOAC Official Method 992.23) or by Kjedahl, using a FOSS Kjeltech 8400 instrument (AACC Method 46-12.01). Nitrogen to protein conversion factor of 6.25 was applied. Moisture content was determined according to AOAC Official Method 925.10 and AACC Method 44-15.02. For nitrogen solubility, $1 \mathrm{~g}$ of flour sample was suspended in water $(1: 10 \mathrm{w} / \mathrm{v})$ and the $\mathrm{pH}$ was adjusted to the desired value. The suspension was mixed on a magnetic stirrer for 30 min and then centrifuged at 3,200 $\times \mathrm{g}$ for 20 minutes. Supernatants were decanted and aliquots were analysed in duplicate by Kjeldahl method. Average nitrogen content of the supernatant was used to calculate nitrogen solubility.

\subsection{Amino Acid Analysis}

Samples were subjected to $24 \mathrm{~h}$ liquid hydrolysis in $6 \mathrm{M} \mathrm{HCl}$ at $110{ }^{\circ} \mathrm{C}$. During hydrolysis, asparagine is hydrolysed to aspartic acid and glutamine is hydrolysed to glutamic acid. The reported amount of aspartic acid and glutamic acid is the sum of their respective components. Both cysteine and tryptophan are destroyed under these hydrolysis conditions and were analysed separately. Cysteine analysis was carried out using performic acid oxidation followed by $24 \mathrm{~h}$ gas phase hydrolysis at $110^{\circ} \mathrm{C}$. Tryptophan analysis was carried out by $24 \mathrm{~h}$ liquid hydrolysis in $5 \mathrm{M} \mathrm{NaOH}$ at $110^{\circ} \mathrm{C}$. After completion of hydrolysis, all amino acids (AAs) were analysed using the Waters AccQTag Ultra chemistry on a Waters Acquity UPLC. Samples were analysed in duplicate and average results were reported.

\subsection{Comparative Proteomic Analysis}

Samples were solubilised in $50 \mathrm{mM}$ triethylammonium bicarbonate buffer containing $0.5 \%$ SDS and probe sonicated, reduced (using dithiothreitol) and alkylated (iodoacetamide). Samples were digested with trypsin for 16 hours at $37{ }^{\circ} \mathrm{C}$. SDS was removed from digested samples using a detergent removal kit followed by a $\mathrm{C} 18$ clean up, then dried down, resuspended in $0.1 \%$ formic acid and used for analysis. Analysis was carried out by reversed phase nano-LC directly coupled in line with a MS/MS system (LC-MS/MS). Samples from each fraction were separated over 90 minute gradients using an Easy Nano LC 1000 (Thermo Scientific). Samples (10 $\mu \mathrm{L}$ ) were injected onto an 'in house' packed solid core Halo C18 $100 \mu \mathrm{m} \times 3 \mathrm{~cm}$ peptide trap column and desalted with $20 \mu \mathrm{L}$ of $0.1 \%$ formic acid. The peptide trap was switched on line with the $\mathrm{C} 1875 \mu \mathrm{m} \times 10 \mathrm{~cm}$ analytical reversed phase column. Peptides were eluted from the column using a linear solvent gradient, step-wise from $5-25 \%$ of buffer [ $99.9 \%$ (v/v) acetonitrile, $0.1 \%$ (v/v) formic acid] for $80 \mathrm{~min}, 25-85 \%$ of buffer for $2 \mathrm{~min}$ and then held at $85 \%$ for $8 \mathrm{~min}$ at a flow rate of $300 \eta \mathrm{L} / \mathrm{min}$ across the gradient.

The column eluate was directed into a nanospray ionization source of the QExactive mass spectrometer (ThermoScientific) and a $1.5 \mathrm{kV}$ electrospray voltage was applied via a liquid junction upstream of the column. Resulting spectra were scanned over the range 350-2000 amu. Automated peak recognition, dynamic exclusion, and MS/MS of the top ten most intense precursor ions at 30\% normalised collision energy were performed. The LC-MS/MS spectra were searched using the MS software Mascot (Matrix Science, London, UK), against the Mungbean reference genome (NCBI Vigna radiata Annotation Release 100) containing 35143 entries (Kang et al., 2014). Peptides were identified with a $1 \%$ false-discovery rate from a concatenated forward-reversed database search. Significant peptide matches were exported and samples compared using NSAF with the program referred to as "SCRappy" (Neilson et al., 2013). Proteins with p-values $<0.05$ following Student's T-Test of NSAF were considered to be differentially expressed between groups.

\section{Results and Discussion}

\subsection{Effect of Processing on Production of Mungbean Protein Isolates}

Wet extraction of processed mungbean flours produced protein isolates (PI), designated herein as MWF-PI, MDF-PI, MRF-PI and MGF-PI. Protein (on dry basis) of the starting flour material, as well as protein (as-is basis) and extraction yield of the respective PIs, is reported in Table 1. Protein content was similar for PIs,

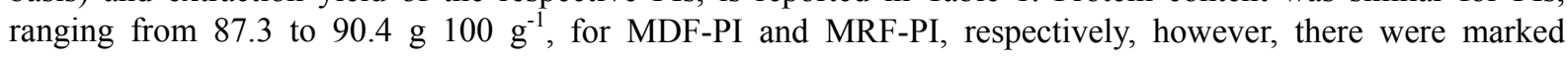
differences in extraction yield. The highest protein yields were reported for MWF-PI and MDF-PI, at 75.7 and 


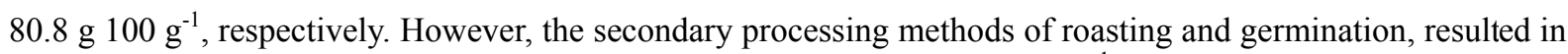

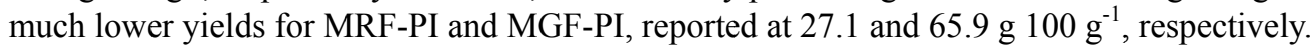

Nitrogen solubility profiles of the processed flours were carried out in duplicate and provided an indication into the variations reported for protein extraction yield (Figure 1). Nitrogen solubility for MRF resulted in a significantly altered profile, in comparison to the other flours, with a non-distinct isoelectric point, impairing precipitation and recovery of protein. Roasting can impart desirable nutritional, flavour and aroma qualities, but high temperatures used during this process may have denatured and modified protein structures, reducing solubility, impacting on extraction yield. Low yield is not desirable or economical for wet processing methods, hence, dry processing technologies such as air classification would be more suitable and should be further investigated (Schutyser \& van der Goot, 2011). Protein extraction yield for MGF-PI was higher, when compared to MRF-PI, but still considerably lower than MWF-PI and MDF-PI. Increased enzyme activity during the germination process results in the hydrolysis of some proteins, increasing nitrogen solubility at $\mathrm{pH} 4-5$. Reduced nitrogen solubility in the alkaline $\mathrm{pH}$ range also helps account for the lower protein extraction yield.

Table 1. Protein content of processed mungbean flours and respective PIs (g $\left.100 \mathrm{~g}^{-1}\right)$

\begin{tabular}{|c|c|c|c|c|}
\hline \multirow{2}{*}{ Sample } & \multicolumn{2}{|c|}{ Protein } & \multirow{2}{*}{ Protein Yield } & \multirow{2}{*}{ Colour of PI } \\
\hline & Flour & PI & & \\
\hline MWF & 24.9 & 87.3 & 75.7 & Light brown \\
\hline MDF & 25.1 & 89.1 & 80.8 & Light yellow \\
\hline MRF & 26.2 & 90.4 & 27.1 & Dark brown \\
\hline MGF & 27.6 & 88.4 & 65.9 & Light brown \\
\hline
\end{tabular}

Note. $*$ Average results reported from duplicate extractions and analysis.



Figure 1. Nitrogen solubility profile for processed mungbean flours

In terms of visual appearance, MWF-PI and MGF-PI appeared light brown in colour, becoming darker for MRF-PI. MDF-PI appeared light yellow in colour, more visually appealing and considered preferable for food applications. Based on colour, protein content and protein yield, MDF-PI may be the most suitable for production at a larger scale. However, MGF-PI was also considered of interest, primarily due to the reported health benefits of germinated flours, such as increased protein digestibility and solubility (in the $\mathrm{pH} 4-7$ range). Both MDF-PI and MGF-PI were selected for further characterisation, including AA composition and a comparative proteomic analysis for a measure of relative protein abundance.

\subsection{AA Composition}

AA composition of MDF-PI and MGF-PI was analysed and compared in Table 2. During AA hydrolysis, asparagine is completely hydrolysed to aspartic acid and glutamine is completely hydrolysed to glutamic acid. Therefore, values reported for aspartic acid and glutamic acid are the sum of their respective components. The 
lowest AA value for both MDF-PI and MGF-PI was sulphur-containing cysteine, reported at 0.33 and $0.34 \mathrm{~g} 100$ $\mathrm{g}^{-1}$, respectively. Tryptophan and methionine were the second and third lowest AAs, with the sulphur-containing

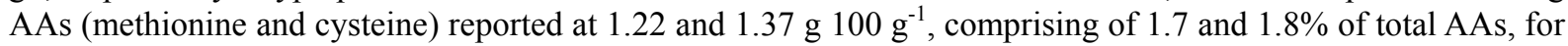
MDF-PI and MGF-PI, respectively. Essential AA content of MDF-PI and MGF-PI was reported at 27.08 and

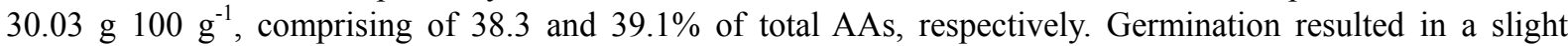
increase in essential AA content for MGF-PI, however, in this study, seeds were germinated for $48 \mathrm{~h}$ and germinating for a longer time period may produce more changes in composition.

Table 2. AA composition of MDF-PI and MGF-PI (g 100 $\mathrm{g}^{-1}$ flour)

\begin{tabular}{lll}
\hline AA & MDF-PI & MGF-PI \\
\hline Alanine & 2.56 & 2.80 \\
Arginine & 5.71 & 5.87 \\
Aspartic acid & 8.45 & 9.26 \\
Cysteine & 0.33 & 0.34 \\
Glutamic acid & 13.18 & 13.94 \\
Glycine & 2.17 & 2.41 \\
Histidine & 2.16 & 2.38 \\
Isoleucine & 3.24 & 3.76 \\
Leucine & 6.08 & 7.01 \\
Lysine & 4.99 & 5.28 \\
Methionine & 0.89 & 1.03 \\
Phenylalanine & 4.99 & 5.61 \\
Proline & 3.02 & 3.32 \\
Serine & 3.78 & 4.04 \\
Threonine & 2.14 & 2.34 \\
Tryptophan & 0.73 & 0.70 \\
Tyrosine & 2.28 & 2.39 \\
Valine & 4.02 & 4.30 \\
Total AAs & 70.72 & 76.78 \\
Essential AAs & $27.08(38.3 \%)$ & $30.03(39.1 \%)$ \\
\hline
\end{tabular}

\subsection{Comparative Proteomic Analysis of MDF-PI and MGF-PI}

A comparative proteomic approach was applied for characterising protein composition and relative abundance in MDF-PI and MGF-PI. Mass spectra generated from this analysis were used to search protein sequence databases, resulting in the inferred identification of 214 proteins, in which, 72 proteins were classified as being common to both PIs, 42 proteins were specific for MDF-PI and 28 proteins were specific for MGF-PI. Identified proteins were compared for relative abundance and reported in terms of average SC and NSAF values (from triplicate MS analysis of a single sample), matching protein description and the identifiable database accession (Table 3). Ratios of NSAFs (MDF-PI/MGF-PI) were reported for comparison of the relative abundance of proteins classified as common for both MDF-PI and MGF-PI. Statistical significance was calculated using t-test $\mathrm{p}$-values and proteins with a p-value of $<0.05$ were considered significantly different between groups and highlighted in bold. However, the interpretation of the data is limited due to the fact that the proteomic analysis is carried out on a single sample of each protein isolate due to the costs associated with this type of analysis. All identified proteins containing $<5 \mathrm{SC}$ were filtered from the dataset and not reported, except for those comparisons in which at least one of the samples contained a value of $>5 \mathrm{SC}$. Protein identifications classified as being specific only for MDF-PI or MGF-PI are reported in Table 4. It should be noted that the absence of a specific protein in either protein isolate does not conclusively mean that protein is not present in the sample. It can only be concluded that the abundance level is too low to be measured on 5 or more occasions as our reporting criteria.

The most abundant proteins identified for both MDF-PI and MGF-PI were globulin storage related proteins (Table 3). Mungbean globulins have previously been purified, characterised and estimated to comprise mostly of the $8 \mathrm{~S}$ globulin protein $(\sim 90 \%)$, with the remainder consisting of the $11 \mathrm{~S}$ and $7 \mathrm{~S}$ globulin protein (Mendoza et al., 2001; Liu et al., 2015). Both the 8S and 7S globulins were shown to cross-react with antibodies to all three types 
of soybean conglycinin ( $8 \mathrm{~S} \alpha, 8 \mathrm{~S} \alpha$ ' and $8 \mathrm{~S} \beta$ isoforms), however, there was no cross-reactivity of mungbean globulins with antibodies to soybean glycinin. $N$-terminal AA sequences of the purified globulins were also found to exhibit strong sequence homology to storage proteins of other pulses (Mendoza et al., 2001). The 8S globulin storage protein consists of three distinct isoforms $(8 \mathrm{~S} \alpha, 8 \mathrm{~S} \alpha$ ' and $8 \mathrm{~S} \beta$ isoforms), reportedly containing high sequence homology (Bernardo et al., 2004). However, in this study, the globulin storage proteins reported in Table 3 were predominantly identified as beta-conglycinin beta chain-like, as well as the alpha chain-like form. Other storage proteins identified were glycinin G4-like and basic 7S globulin 2-like proteins. In any case, these highly abundant storage proteins do not change very much between the two protein isolates.

There were a total of 8 proteins $(p<0.05)$ that were significantly different in relative abundance (highlighted in bold in Table 3). The main difference occurring between MDF-PI and MGF-PI is that the level of protein folding and stabilisation proteins is going down in MGF-PI, which may be expected as the seed is beginning to germinate. Proteins like dehydrins and chaperones present in the seeds are there to stabilise the enzymes as the seed begins the germination process, however, these particular proteins may be expected to disappear or turnover during the early stages of this process, which is reflective in the protein composition and relative abundance of these isolates.

Table 3. Inferred identity and relative abundance of those proteins classified as common for MDF-PI and MGF-PI. NSAF ratios of MDF-PI/MGF-PI that are statistically significant $(\mathrm{p}<0.05)$ are highlighted in bold

\begin{tabular}{|c|c|c|c|c|c|c|}
\hline \multirow{2}{*}{ Identifier } & \multicolumn{2}{|c|}{ SC } & \multirow{2}{*}{$\begin{array}{l}\text { Matching protein description } \\
\text { [Vigna radiata } \text { var. Radiata] }\end{array}$} & \multicolumn{2}{|c|}{ NSAF } & \multirow{2}{*}{ Ratio } \\
\hline & MDF-PI & MGF-PI & & MDF-PI & MGF-PI & \\
\hline gi|951066354|ref|XP_014523937.1| & 406 & 440 & Beta-conglycinin, beta chain-like isoform X1 & 0.14395 & 0.14081 & 1.02231 \\
\hline gi|951067727|ref|XP_014524354.1| & 371 & 392 & Beta-conglycinin, beta chain-like & 0.13128 & 0.12650 & 1.03778 \\
\hline gi|950940165|ref|XP_014492536.1| & 226 & 286 & Beta-conglycinin, beta chain-like & 0.08550 & 0.09262 & 0.92318 \\
\hline gi|951002540|ref|XP_014507363.1| & 227 & 234 & Beta-conglycinin, beta chain-like & 0.08483 & 0.07903 & 1.07342 \\
\hline gi|951066306|ref|XP_014523923.1| & 182 & 268 & Beta-conglycinin, beta chain-like & 0.07115 & 0.10563 & 0.67358 \\
\hline gi|951033982|ref|XP_014515878.1| & 149 & 164 & Beta-conglycinin, beta chain-like & 0.05347 & 0.05102 & 1.04804 \\
\hline gi|951056419|ref|XP_014521758.1| & 156 & 143 & Glycinin G4-like & 0.04160 & 0.03316 & 1.25461 \\
\hline gi|951066351|ref|XP_014523936.1| & 136 & 154 & Beta-conglycinin, alpha chain-like & 0.04102 & 0.04103 & 0.99974 \\
\hline gi|951066358|ref|XP_014523938.1| & 122 & 243 & Beta-conglycinin, beta chain-like isoform $\mathrm{X} 2$ & 0.03640 & 0.06763 & 0.53830 \\
\hline gi|951067725|ref|XP_014524353.1| & 31 & 39 & Beta-conglycinin, beta chain-like, partial & 0.02129 & 0.02310 & 0.92169 \\
\hline gi|951042174|ref|XP_014518107.1| & 46 & 41 & Basic 7S globulin 2-like & 0.01833 & 0.01475 & 1.24268 \\
\hline gi|951005658|ref|XP_014508213.1| & 40 & 10 & $\begin{array}{l}\text { Low quality protein: } \\
\text { late embryogenesis abundant protein D-29 }\end{array}$ & 0.01733 & 0.00343 & 5.04759 \\
\hline gi|951006538|ref|XP_014508498.1| & 11 & 4 & Uncharacterised protein LOC106768046 & 0.01533 & 0.00456 & 3.36211 \\
\hline gi|951006474|ref|XP_014508481.1| & 14 & 18 & 1-Cys peroxiredoxin & 0.01094 & 0.01250 & 0.87529 \\
\hline gi|950930231|ref|XP_014503883.1| & 13 & 1 & Dehydrin DHN3-like & 0.00934 & 0.00075 & 12.54170 \\
\hline gi|950968931|ref|XP_014499690.1| & 48 & 50 & Seed linoleate 9S-lipoxygenase-3 & 0.00913 & 0.00797 & 1.14587 \\
\hline gi|951021491|ref|XP_014512682.1| & 27 & 24 & Sucrose-binding protein-like & 0.00891 & 0.00680 & 1.31110 \\
\hline gi|950943234|ref|XP_014493768.1| & 8 & 5 & Peptidyl-prolyl cis-trans isomerase 1 & 0.00859 & 0.00506 & 1.69741 \\
\hline gi|951056290|ref|XP_014521723.1| & 11 & 6 & Uncharacterised protein LOC106778296 & 0.00809 & 0.00353 & 2.29302 \\
\hline gi|950986379|ref|XP_014503555.1| & 7 & 7 & $17.5 \mathrm{kDa}$ class I heat shock protein-like & 0.00793 & 0.00748 & 1.06008 \\
\hline gi|951000293|ref|XP_014506761.1| & 12 & 22 & $\begin{array}{l}\text { Glucose and ribitol dehydrogenase } \\
\text { homolog 1-like }\end{array}$ & 0.00740 & 0.01031 & 0.71800 \\
\hline gi|951023258|ref|XP_014513134.1| & 9 & 9 & Albumin-2-like & 0.00691 & 0.00656 & 1.05352 \\
\hline gi|951022780|ref|XP_014513011.1| & 9 & 7 & Peroxygenase & 0.00667 & 0.00489 & 1.36438 \\
\hline gi|951014217|ref|XP_014510496.1| & 25 & 22 & Heat shock $70 \mathrm{kDa}$ protein & 0.00643 & 0.00510 & 1.25951 \\
\hline gi|950993033|ref|XP_014504815.1| & 14 & 14 & Alcohol dehydrogenase 1-like & 0.00631 & 0.00540 & 1.16768 \\
\hline gi|951066326|ref|XP_014523928.1| & 22 & 28 & Beta-conglycinin, beta chain-like & 0.00600 & 0.00660 & 0.90929 \\
\hline gi|951048093|ref|XP_014519608.1| & 21 & 14 & Canavalin & 0.00501 & 0.00290 & 1.72687 \\
\hline gi|951065326|ref|XP_014523717.1| & 13 & 15 & Luminal-binding protein, partial & 0.00469 & 0.00443 & 1.05905 \\
\hline gi|950940004|ref|XP_014492244.1| & 3 & 6 & 60S ribosomal protein $\mathrm{L} 12$ & 0.00403 & 0.00508 & 0.79281 \\
\hline gi|950933029|ref|XP_014511428.1| & 7 & 4 & Actin-1-like & 0.00358 & 0.00198 & 1.80356 \\
\hline
\end{tabular}




\begin{tabular}{|c|c|c|c|c|c|c|}
\hline gi|951040313|ref|XP_014517640.1| & 6 & 4 & $\begin{array}{l}\text { Glucose and ribitol dehydrogenase } \\
\text { homolog 1-like }\end{array}$ & 0.00352 & 0.00171 & 2.05819 \\
\hline gi|950933283|ref|XP_014511756.1| & 19 & 28 & Alpha-1,4 glucan phosphorylase L isozyme & 0.00327 & 0.00377 & 0.86855 \\
\hline gi|950968907|ref|XP_014499686.1| & 17 & 26 & Seed linoleate 9S-lipoxygenase-2 & 0.00325 & 0.00445 & 0.72939 \\
\hline gi|950943809|ref|XP_014493887.1| & 12 & 20 & heat shock cognate $70 \mathrm{kDa}$ protein 2 & 0.00312 & 0.00447 & 0.69756 \\
\hline gi|951043323|ref|XP_014518340.1| & 6 & 4 & Actin-7-like & 0.00292 & 0.00183 & 1.59178 \\
\hline gi|950925699|ref|XP_014494982.1| & 6 & 4 & $\begin{array}{l}\text { Formate dehydrogenase } 1 \text {, } \\
\text { mitochondrial-like isoform } \mathrm{X} 1\end{array}$ & 0.00286 & 0.00227 & 1.26307 \\
\hline gi|950951948|ref|XP_014495815.1| & 11 & 19 & Heat shock cognate $70 \mathrm{kDa}$ protein 2 & 0.00286 & 0.00416 & 0.68678 \\
\hline gi|950979939|ref|XP_014501963.1| & 7 & 8 & Protein disulfide-isomerase-like & 0.00235 & 0.00226 & 1.04016 \\
\hline gi|950977676|ref|XP_014501534.1| & 3 & 9 & 14-3-3-like protein isoform $\mathrm{X} 1$ & 0.00201 & 0.00552 & 0.36354 \\
\hline gi|951068867|ref|XP_014489923.1| & 4 & 5 & $\begin{array}{l}\text { Glyceraldehyde-3-phosphate dehydrogenase, } \\
\text { cytosolic-like }\end{array}$ & 0.00188 & 0.00143 & 1.31104 \\
\hline gi|323149044|ref|YP_004222824.1| & 5 & 3 & ATPase subunit 1 (mitochondrion) & 0.00169 & 0.00087 & 1.93025 \\
\hline gi|951027555|ref|XP_014514203.1| & 5 & 8 & ATP synthase subunit beta, mitochondrial & 0.00169 & 0.00200 & 0.84141 \\
\hline gi|950945335|ref|XP_014494232.1| & 7 & 3 & Poly [ADP-ribose] polymerase 3 & 0.00161 & 0.00060 & 2.68117 \\
\hline gi|950992302|ref|XP_014504685.1| & 6 & 13 & Heat shock cognate protein 80 & 0.00147 & 0.00252 & 0.58550 \\
\hline gi|950974705|ref|XP_014500967.1| & 5 & 8 & Nudix hydrolase 3-like & 0.00131 & 0.00165 & 0.78994 \\
\hline gi|950934982|ref|XP_014515635.1| & 4 & 10 & Heat shock protein 83 & 0.00099 & 0.00200 & 0.49636 \\
\hline gi|950961465|ref|XP_014497885.1| & 1 & 8 & 14-3-3-like protein A & 0.00096 & 0.00460 & 0.20799 \\
\hline gi|950929654|ref|XP_014502725.1| & 1 & 6 & 40S ribosomal protein S3-1-like & 0.00082 & 0.00392 & 0.20814 \\
\hline gi|951041425|ref|XP_014517933.1| & 1 & 7 & Desiccation-related protein PCC13-62 & 0.00075 & 0.00265 & 0.28162 \\
\hline gi|951001309|ref|XP_014507048.1| & 1 & 5 & $\begin{array}{l}\text { Aspartate-tRNA ligase, } \\
\text { chloroplastic/mitochondrial }\end{array}$ & 0.00051 & 0.00121 & 0.42315 \\
\hline gi|950952971|ref|XP_014496061.1| & 1 & 7 & Chaperone protein ClpB1 & 0.00029 & 0.00110 & 0.26007 \\
\hline gi|950976550|ref|XP_014501310.1| & 1 & 5 & Heat shock $70 \mathrm{kDa}$ protein 15 -like & 0.00023 & 0.00070 & 0.32142 \\
\hline
\end{tabular}

Table 4. Inferred identity and relative abundance of those proteins classified as specific for either MDF-PI or MGF-PI.

\begin{tabular}{|c|c|c|c|}
\hline Identifier & SC & $\begin{array}{l}\text { Matching protein description } \\
\text { [Vigna radiata var. Radiata] }\end{array}$ & NSAF \\
\hline \multicolumn{4}{|l|}{$M D F-P I$ specific proteins } \\
\hline gi|950951134|ref|XP_014495577.1| & 8 & Embryonic protein DC-8-like & 0.00500 \\
\hline gi|951017322|ref|XP_014511359.1| & 5 & Universal stress protein YxiE & 0.00458 \\
\hline gi|950960424|ref|XP_014497650.1| & 6 & Actin-11 & 0.00290 \\
\hline gi|950933402|ref|XP_014511960.1| & 6 & Elongation factor 1-alpha & 0.00223 \\
\hline gi|951016290|ref|XP_014511078.1| & 6 & Embryonic protein DC-8-like & 0.00211 \\
\hline gi|951028515|ref|XP_014514444.1| & 5 & Serine carboxypeptidase-like & 0.00191 \\
\hline gi|950929466|ref|XP_014502187.1| & 8 & TSC22 domain family protein 1-like & 0.00135 \\
\hline \multicolumn{4}{|l|}{$M G F-P I$ specific proteins } \\
\hline gi|950953641|ref|XP_014496230.1| & 5 & Enolase & 0.00176 \\
\hline gi|951058926|ref|XP_014522292.1| & 7 & 14-3-3-like protein & 0.00373 \\
\hline gi|951011581|ref|XP_014509823.1| & 5 & Glucose-6-phosphate 1-dehydrogenase, cytoplasmic isoform-like & 0.00135 \\
\hline gi|950975283|ref|XP_014501071.1| & 5 & Eukaryotic translation initiation factor 3 subunit B-like & 0.00084 \\
\hline gi $|950991600|$ ref $\left|X P \_014504547.1\right|$ & 9 & Low-temperature-induced cysteine proteinase-like & 0.00223 \\
\hline gi|950935539|ref|XP_014517055.1| & 7 & Isocitrate dehydrogenase [NADP] & 0.00215 \\
\hline gi|950994414|ref|XP_014505129.1| & 5 & OBERON-like protein & 0.00114 \\
\hline gi|950974172|ref|XP_014500870.1| & 8 & Acetyl-CoA carboxylase 1-like isoform X1 & 0.00038 \\
\hline
\end{tabular}




\section{Conclusion}

This study provided significant information on the composition of protein isolates prepared from processed flours milled from a commercial Australian mungbean variety (Crystal). Processing methods were shown to impart significant differences on protein yield, which can have an economical impact in large-scale wet processing. Understanding the impact of different processing methods on protein concentration, composition, solubility, as well as other functional attributes is important for producing value-added high protein fractions for food applications. Innovative wet and dry processing of pulses such as mungbean, combined with comparative proteomic analysis tools for measuring protein composition and relative abundance, will provide an effective platform for producing concentrated protein fractions with enhanced nutritional qualities and functionality. This study provides a foundation for further research focussed on reducing anti-nutritional factors, increasing protein digestibility and the bioavailability of nutrients from pulses. Increasing nutritional qualities and associated health benefits of value-added pulse products could potentially lead to wider consumer acceptance and increased consumption, which in turn, will contribute to the future sustainability of food production and the supply of protein.

\section{Acknowledgements}

I would like to acknowledge the work carried out by the Analytical Laboratory team at the Australian Export Grains Innovation Centre in Sydney. Part of this work was undertaken at APAF with the infrastructure provided by the Australian Government through the National Collaborative Research Infrastructure Strategy (NCRIS).

\section{References}

Aiking, H. (2011). Future protein supply. Trends in Food Science and Technology, 22, 112-120. https://doi.org/ 10.1016/j.tifs.2010.04.005

Bernardo, A. E. N., Garcia, R. N., Adachi, M., \& Tecson-Mendoza, E. M. (2004). 8S globulin of mungbean (Vigna radiata $(\mathrm{L}$.$) Wilczek): Cloning and characterisation of its cDNA isoforms, expression in Escherichia$ coli, purification, and crystallisation of the major recombinant $8 \mathrm{~S}$ isoform. Journal of Agricultural and Food Chemistry, 52, 2552-2560. https://doi.org/10.1021/jf0305938

Boye, J., Zare, F., \& Pletch, A. (2010). Pulse proteins: Processing, characterisation, functional properties and applications in food and feed. Food Research International, 43, 414-431. https://doi.org/10.1016/j.foodres. 2009.09.003

Fan, T. Y., \& Sosulski, F. W. (1974). Dispersibility and isolation of proteins from legume flours. Canadian Institute of Food Science and Technology Journal, 7, 256-261. https://doi.org/10.1016/S0315-5463(74) 73923-2

Kang, Y. J., Kim, S. K., Kim, M. J., Lestari, P., Kim, K. H., Ha, B.-K., ... Lee, S.-H. (2014). Genome sequence of mungbean and insights into evolution within Vigna species. Nature Communications, 5, 1-9. https://doi.org/10.1016/S0315-5463(74)73923-2

Knorr, D., Froehling, A., Jaeger, H., Reineke, K., Schlueter, O., \& Schoessler, K. (2011). Emerging technologies in food processing. Annual Reviews in Food Science and Technology, 2, 203-235. https://doi.org/10.1146/ annurev.food.102308.124129

Li, W., Shu, C., Yan, S., \& Shen, Q. (2010). Characteristics of sixteen mungbean cultivars and their protein isolates. International Journal of Food Science and Technology, 45, 1205-1211. https://doi.org/10.1111/ j.1365-2621.2010.02259.x

Liu, H., Liu, H., Yan, L., Cheng, X., \& Kang, Y. (2015). Functional properties of 8S globulin fractions from 15 mungbean (Vigna radiata (L.) Wilczek) cultivars. International Journal of Food Science and Technology, 50, 1206-1214. https://doi.org/10.1111/ijfs.12761

Liu, H., Sadygov, R. G., \& Yates, J. R. (2004). A model for random sampling and estimation of relative protein abundance in shotgun proteomics. Analytical Chemistry, 76, 4193-4201. https://doi.org/10.1021/ac0498563

Lundgren, D. H., Hwang, S., Wu, L., \& Han, D. K. (2010). Role of spectral counting in quantitative proteomics. Expert Reviews in Proteomics, 7, 39-53. https://doi.org/10.1586/epr.09.69

Matros, A., Kaspar, S., Witzel, K., \& Mock, H. P. (2011). Recent progress in liquid chromatography-based separation and label-free quantitative plant proteomics. Phytochemistry, 72, 963-974. https://doi.org/ 10.1016/j.phytochem.2010.11.009 
Mendoza, E. M. T., Adachi, M., Bernardo, A. E. N., \& Utsumi, S. (2001). Mungbean (Vigna radiata (L.) Wilczek) globulins: Purification and characterisation. Journal of Agricultural and Food Chemistry, 49, 1552-1558. https://doi.org/10.1021/jf001041h

Mirzaei, M., Wu, Y., Handler, D., Maher, T., Pascovici, D., Ravishankar, P., ... Willows, R. D. (2016). Applications of quantitative proteomics in plant research. In G. H. Salekdeh (Ed.), Agricultural Proteomics (Vol. 1, pp. 1-23). Springer International Publishing, Switzerland. https://doi.org/10.1007/978-3-31943275-5_1

Mosley, A. L., Florens, L., Wen, Z., \& Washburn, M. P. (2009). A label free quantitative proteomic analysis of the Saccharomyces cerevisiae nucleus. Journal of Proteomics, 72, 10-120. https://doi.org/10.1016/j.jprot. 2008.10.008

Nair, R. M., Yang, R.-Y., Easdown, W. J., Thavarajah, D., Thavarajah, P., d’A Hughes, J., \& Keatinge, J. D. H. (2013). Biofortification of mungbean (Vigna radiata) as a whole food to enhance human health. Journal of the Science of Food and Agriculture, 93, 1805-1813. https://doi.org/10.1002/jsfa.6110

Neilson, K. A., Keighley, T., Pascovici, D., Cooke, B., \& Haynes, P. A. (2013). Label-free quantitative shotgun proteomics using normalised spectral abundance factors. In M. Zhou \& T. Veenstra (Eds.), Proteomics for Biomarker Discovery: Methods and Protocols, Methods in Molecular Biology (Vol. 1002, pp. 205-222). Springer Science+Business Media.

Patterson, C. A., Curran, J., \& Der, T. (2017). Effect of processing on antinutrient compounds in pulses. Cereal Chemistry, 94, 2-10. https://doi.org/10.1094/CCHEM-05-16-0144-FI

Podwojski, K., Eisenacher, M., Kohl, M., Turewicz, M., Meyer, H. E., Rahnenführer, J., \& Stephan, C. (2010). Peek a peak: A glance at statistics for quantitative label-free proteomics. Expert Reviews in Proteomics, 7, 249-261. https://doi.org/10.1586/epr.09.107

Schutyser, M. A. I., \& van der Goot, A. J. (2011). The potential of dry fractionation processes for sustainable plant protein production. Trends in Food Science and Technology, 22, 154-164. https://oi.org/10.1016/ j.tifs.2010.11.006

Singh, A. K., Rehal, J., Kaur, A., \& Jyot, G. (2015). Enhancement of attributes of cereals by germination and fermentation: A review. Critical Reviews in Food Science and Nutrition, 55, 1575-1589. https://doi.org/ 10.1080/10408398.2012.706661

Sun-Waterhouse, D., Zhao, M., \& Waterhouse, G. I. N. (2014). Protein modification during ingredient preparation and food processing: Approaches to improve food processability and nutrition. Food and Bioprocess Technology, 7, 1853-1893. https://doi.org/10.1007/s11947-014-1326-6

Tharanathan, R. N., \& Mahadevamma, S. (2003). Grain legumes-A boon to human nutrition. Trends in Food Science and Technology, 14, 507-518. https://doi.org/10.1016/j.tifs.2003.07.002

Thelen, J. J., \& Peck, S. C. (2007). Quantitative proteomics in plants: Choices in abundance. Plant Cell, 19, 3339-3346. https://doi.org/10.1105/tpc.107.053991

Thompson, L. U. (1977). Preparation and evaluation of mungbean protein isolates. Journal of Food Science, 42 , 202-206. https://doi.org/10.1111/j.1365-2621.1977.tb01252.x

Vaz Patto, M. C., Amarowicz, R., Aryee, A. N. A., Boye, J. I., Chung, H.-J., Martín-Cabrejas, M. A., \& Domoney, C. (2015). Achievements and challenges in improving the nutritional quality of food legumes. Critical Reviews in Plant Sciences, 34, 105-143. https://doi.org/10.1080/07352689.2014.897907

Wang, M., Jiang, L., Li, Y., Liu, Q., Wang, S., \& Sui, X. (2011). Optimisation of extraction process of protein isolate from mungbean. Procedia Engineering, 15, 5250-5258. https://doi.org/10.1016/j.proeng.2011.08.973

Zhang, B., VerBerkmoes, N. C., Langston, M. A., Uberbacher, E., Hettich, R. L., \& Samatova, N. F. (2006). Detecting differential and correlated protein expression in label-free shotgun proteomics. Journal of Proteome Research, 5, 2909-2918. https://doi.org/10.1021/pr0600273

Zybailov, B. L., Florens, L., \& Washburn, M. P. (2007). Quantitative shotgun proteomics using a protease with broad specificity and normalised spectral abundance factors. Molecular BioSystems, 3, 354-360. https://doi.org/10.1039/b701483j

Zybailov, B., Mosley, A. L., Sardiu, M. E., Coleman, M. K., Florens, L., \& Washburn, M. P. (2006). Statistical analysis of membrane proteome expression changes in Saccharomyces cerevisiae. Journal of Proteome Research, 5, 2339-2347. https://doi.org/10.1021/pr060161n 


\section{Copyrights}

Copyright for this article is retained by the author(s), with first publication rights granted to the journal.

This is an open-access article distributed under the terms and conditions of the Creative Commons Attribution license (http://creativecommons.org/licenses/by/4.0/). 